DOI: $10.14451 / 2.122 .51$

\title{
ЗАДАЧИ ГОСУДАРСТВЕННОГО УПРАВЛЕНИЯ НЕДВИЖИМОСТЬЮ В СВЕТЕ СТРАТЕГИЧЕСКИХ НАПРАВЛЕНИЙ РАЗВИТИЯ РОССИЙСКОЙ ФЕДЕРАЦИИ
}

\author{
(c) 2018 Камынина Надежда Ростиславовна \\ кандидат технических наук, доцент \\ доцент кафедры земельного права и государственной регистрации недвижимости \\ Московский государственный университет геодезии и картографии \\ 105064, г. Москва, Гороховский пер., 4 \\ E-mail: kamyninan@gmail.com
}

В статье рассматриваются актуальные задачи управления недвижимостью в рамках стратегии развития Российской Федерации до 2024 года в соответствии с Указом Президента и Постановлением Правительства. В частности, выявлены приоритетные области государственного управления недвижимостью: совершенствование управления государственной собственностью, в том числе недвижимым имуществом и земельными ресурсами, а также повышение качества государственного управления недвижимостью на базе ускорения процессов его цифровизации.

Ключевые слова: управление недвижимостью, стратегические направления развития, качество, цифровизация.

Актуальность исследуемой темы состоит в необходимости определения ключевых задач управления недвижимостью как важнейшего фактора экономики и национального богатства для достижения долгосрочных целей развития Российской Федерации. Стратегические направления развития РФ связаны с реализацией положений Указа Президента РФ «О национальных целях и стратегических задачах развития РФ на период до 2024 года» от 7 мая 2018 г. № 204 [1], определяющего цели, задачи и приоритеты научно - технологического и социально-экономического развития страны, которые включают достижение [2]:

1) устойчивого роста численности населения РФ и повышение продолжительности жизни;

2) устойчивого роста реальных доходов граждан, уровня пенсионного обеспечения, снижения уровня бедности в РФ;

3) улучшения жилищных условий населения;

4) ускорения технологического развития РФ и увеличения количества организаций, осуществляющих технологические инновации;

5) ускоренного внедрения цифровых технологий в экономике и социальной сфере;

6) вхождения РФ в число пяти крупнейших экономик мира, при высоких темпах экономического роста и сохранении макроэкономической стабильности;

7) создания в базовых отраслях экономики высокопроизводительных секторов, ориентированных на экспорт, развивающихся на основе современных технологий и обеспеченных высококвалифицированными кадрами.

В рамках выделенных мер по достижению намеченных стратегических целей, в первую очередь, необходимо создать условия для экономического роста, среди которых значительную роль играет управление государственной собственностью, в том числе недвижимым имуществом в целом и земельными ресурсами в частности. В этом контексте целью является повышение эффективности управления и распоряжения государственным и муниципальным недвижимым имуществом, а ключевыми задачами выступают [2]:

1) совершенствование приватизации;

2) принятие $\Phi 3$ «О государственном и муниципальном имуществе»;

3) повышение эффективности администрирования доходов от управления земельными участками;

4) совершенствование системы государственного материального резерва;

5) совершенствование механизмов управления земельными ресурсами в РФ, включая: развитие института землеустройства; наполнение ЕГРН достоверными сведениями; расширение системы оборота, учета и защиты земель сельскохозяйственного назначения; совершенствование земельного надзора, законодательства в части порядка применения принципа 
приобретательной давности, установление порядка передачи земельных участков.

Кроме этого, среди важнейших мер по достижению стратегических целей развития РФ особо выделяется необходимость повышения качества государственного управления. Такое решение во многом обосновано в научной литературе [5,6], где качество определяется как один из фундаментальных факторов развития человечества. Направления повышения качества государственного управления строятся на основе модернизации его системы [2] и включают:

- повышение качества предоставления государственных (муниципальных) услуг, функций и сервисов населению;

- использование цифровых технологий;

- внедрение стратегического и проектного управления;

- формирование высококвалифицированных кадров государственной службы;

- развитие механизмов оценки обратной связи регулирующего воздействия;

- расширение участия граждан в государственном (муниципальном) управлении.

В области повышения качества государственного управления недвижимым имуществом главной целью является достижение удовлетворенности потребителей результатами управления недвижимостью, определяющей приоритетное развитие государственных (муниципальных) услуг в сфере недвижимости. Это предполагает, в частности, усиление административных регламентов, цифровизацию, а также обратную связь в форме оценки гражданами эффективности деятельности органов исполнительной власти и их структур с учетом качества предоставления ими государственных услуг в области недвижимого имущества (НИ), в том числе обязательную оценку [3] следующих услуг:

1) регистрации прав на НИ и сделок с ним;

2) кадастрового учета НИ;

3) предоставления сведений, внесенных в кадастр НИ;

4) предоставления сведений, содержащихся в Едином государственном реестре прав на НИ и сделок с ним.

Прогрессивность развития современного общества определяется цифровой экономикой. В связи с этим базовой платформой государственного управления недвижимым имуществом и его качества должна стать цифровизация. По сути, это означает более ши- рокое применение цифровых технологий при управлении недвижимым имуществом, в целом позволяющее повысить результативность и эффективность процессов взаимодействия с государством в этой области, упростить ведение основных управленческих процессов, связанных с недвижимостью, а также сделать их более прозрачными.

В целях развития цифровых технологий в государственном управлении недвижимым имуществом необходимо законодательно урегулировать вопросы ведения государственных информационных ресурсов НИ, определить правила систематизации информации в данных ресурсах НИ, а также гармонизировать информацию между различными информационными ресурсами органов и структур государственной власти. В рамках этих задач необходимы меры по внедрению «цифровизации», цифровых технологий и платформенных решений в практическую деятельность органов и структур государственного управления недвижимым имуществом, так как учет его оборота и регистрация представляет собой информационную систему, тесно связанную с информационными технологиями. В настоящий момент цифровизация государственного управления недвижимым имуществом предполагает, прежде всего, перевод документации в цифровой формат с применением принципа digital first, а также реструктуризацию на этой основе управленческих процессов с точки зрения их эффективности [4].

В целом задачами в области цифровизации государственного управления НИ являются:

- снижение административных издержек и нагрузки на бизнес по представлению отчетности в секторе НИ;

- создание больших и малых баз данных, связанных с недвижимостью, а также блокчейн-платформ на основе когнитивных моделей процессов управления недвижимостью;

- внедрение автоматизированных систем с применением технологий искусственного интеллекта, обеспечивающих подход к эксплуатации и обслуживанию объектов недвижимости с максимальным уровнем стандартизации и унификации;

- встраивание данных в процессы принятия решений, автоматические алгоритмы принятия решений, принципиальный реинжиниринг процессов, мониторинг ситуации в режиме реального времени; 
- развитие системы распределенного реестра;

- совершенствование и развитие связанности ведомственных систем управления НИО [7];

- создание мониторинга для стратегического планирования госуправления НИ в процессе перехода на цифровой формат;

- повышение скорости и качества оказания услуг и минимизация очного контакта с госорганами.

В развитие цифровизации государственного управления НИ автором предлагается разработка национального проекта по цифровой оценке качества государственного управления недвижимым имуществом организаций по регионам России и в целом для страны для осуществления мониторинга его состояния, выявления корреляции с целевыми социально - экономически- ми показателями развития регионов и определения мероприятий для улучшения качества управления НИ в интересах достижения высоких результативных целевых показателей.

В заключение можно отметить значительную роль государственного управления недвижимым имуществом в реализации основных направлений стратегического развития Российской федерации на период до 2024 года и необходимость его совершенствования в следующих ключевых областях:

1) управление государственной собственностью, в том числе в части недвижимого имущества и земельных ресурсов;

2) повышение качества государственного управления недвижимым имуществом, нацеленного на удовлетворенность потребителей путем усиления процессов цифровизации.

\section{Библиографический список}

1. Указ Президента РФ от 7 мая 2018 г. № 204 «О национальных целях и стратегических задачах развития РФ на период до 2024 года».

2. Постановление Правительства Российской Федерации от 29 сентября 2018 г. «Основные направления деятельности Правительства Российской Федерации на период до 2024 года».

3. Постановление Правительства Российской Федерации от 12 декабря 2012 г. N1284 «Об оценке гражданами эффективности деятельности руководителей территориальных органов федеральных органов исполнительной власти (их структурных подразделений) с учетом качества предоставления ими государственных услуг, а также о применении результатов указанной оценки как основания для принятия решений о досрочном прекращении исполнения соответствующими руководителями своих должностных обязанностей».

4. Банке Б., Бутенко В., Мишенина Д., Полунин К., Степаненко А., Сычева Е. Россия онлайн: четыре приоритета для прорыва в цифровой экономике. [Электронный ресурс]. - The Boston Consulting Group.- Октябрь, 2017. 28 с.- Режим доступа: http://image-src.bcg.com/Images/Russia-Online_tcm27-178074.pdf.

5. Горбашко Е.А. Повышение качества управления на основе менеджмента качества // Стандарты и качество. 2009. № 3. С. $88-89$.

6. Окрепилов В.В. Повышение качества государственных услуг посредством внедрения систем менеджмента качества // Теория и философия хозяйства. 2012. № 6. С. 9-12.

7. Петров М., Буров В., Шклярук М., Шаров А. Государство как платформа. (Кибер) Государство для цифровой экономики. Цифровая трансформация. [Электронный ресурс]. // Центр стратегических разработок. Москва. Апрель, 2018. 52 с. Режим доступа: https:/www.csr.ru/wp-content/uploads/2018/05/GOSUDARSTVO-KAKPLATFORMA_internet.pdf. 